\title{
IGNÁC GOLDZIHER'S REPORT \\ ON THE BOOKS BROUGHT FROM THE ORIENT FOR THE HUNGARIAN ACADEMY OF SCIENCES
}

\author{
ADAM MESTYAN \\ HARVARD UNIVERSITY
}

\begin{abstract}
This paper contains the English translation of Ignác Goldziher's Hungarian essay Report on the Books Brought from the Orient for the Hungarian Academy of Sciences with Regard to the Conditions of the Printing Press in the Orient (1874). The introduction provides the historical and scholarly context of the article. The Arabic printed books Goldziher bought in Egypt reflect his understanding of a specialized Arabic Studies library in the 1870s. The general argument is that Goldziher connected the Arab nation and Arabic texts based on the Hungarian and German concepts of liberal nationalism. This connection instrumentalized religious texts for a non-religious goal.
\end{abstract}

On Sunday 19 April 1874 a banquet was held in Pest. It was organized by the linguist M. Ballagi (1815-91) to celebrate two young Orientalists: G. Bálint (1844-1913), returning from his five-year journey in Russia and Central Asia, and I. Goldziher (1850-1921), returning from Ottoman Syria and Egypt after seven months. Some senior scholars, Á. Vámbéry (1832-1913), F. Toldy (1805-75) and J. Fogarassy (Fogarasi, 1801-78) were also invited. Ballagi's son (A. Ballagi, 1853-1928) recollects much later that 'poor Goldziher could barely say anything during the dinner because he had hardly opened his mouth to say something about Damascus, when Toldy immediately interrupted him saying that Damascus in Hungarian was "Dömöczk" which, according to him, reflected more truly the Arabic pronunciation, "Dimishk" [Dimashq]. Goldziher replied that Toldy was right and added that in fact "Damascus" had been created from the Hebrew 'Damesek' with a Latin ending.'

1 A. Ballagi, 'Emlékezés Goldziher Ignáczra', Vasárnapi Újság, 68 (1921), 268-9. M. Ballagi's Hebrew Grammar for Elementary Schools in Hungarian was updated by Goldziher in 1872. 
also recalls that during this banquet Vámberry debated the origins of an old Hungarian poem with Toldy. ${ }^{2}$ The next day, on 20 April 1874, Goldziher presented a report to the First Section (Linguistics and Literary Scholarship) of the Hungarian Academy of Sciences.

The year before Goldziher had been sent by Á. Trefort (1817-88), Minister of Culture and Education, to study 'the vernacular and official languages' of Syria and Egypt. Goldziher set off on 15 September 1873 and arrived back in Pest around late March 1874. His journey included approximately two months of study at al-Azhar in Cairo. ${ }^{3}$ L.I. Conrad has analysed the significance of this travel for Goldziher's scholarly career. ${ }^{4}$ In addition to language-learning, the young Goldziher was also entrusted to acquire books for the library of the Hungarian Academy of Sciences and received a sum for this purpose. The report for the Academy is about these books.

The presentation, the second one of the session, was recorded in the minutes as 'Dr. Ignácz Goldziher as a guest and emissary reads his Report'. His audience included linguists, among them the guests from the banquet (with the exception of Toldy). After he had finished, the President of the Section, F. Pulszky (1817-94), thanked him for 'fulfilling his task so diligently and with such success, and

2 A szerkesztő [A. Ballagi], 'Eszterházy Pál Nádor verseiről', Irodalomtörténeti Közlemények, 2:4 (1892), 522-5.

3 The day of departure is known from his diary but his return date is not clear. He attended a prayer 'the Friday before 'Āshūrā' in Cairo. 'Āshūrā' was on 10 Muharram 1291 hijrì: 27 or 28 February 1874 . Shortly after this event, hearing of his father's fatal illness, Goldziher left Cairo, spent two days in Alexandria, crossed the Mediterranean (in a maximum of five days), spent another two days in Trieste, finally arriving in Székesfehérvár where he spent a few days with his family. Only then did he continue to Pest. I. Goldziher, Napló (Budapest 1984), 98-100. A bill, dated 1 March 1874, of the Austro-Hungarian Lloyd Navigation Company, indicates that books were sent from Alexandria to the Hungarian Academy of Sciences, in K 1294 (1874), Régi Könyvek és Kézirattár, Magyar Tudományos Akadémia (Rare Books and Manuscript Collection, Hungarian Academy of Sciences, henceforth MTARK). Most probably these were the books Goldziher had bought in Cairo. In his diary he says that the Austro-Hungarian Consul-General helped to post his books when he was in Alexandria. Thus he must have been in Alexandria on 1 March. Consequently, his statement that he spent almost four months studying at al-Azhar is possibly an exaggeration; he studied there for approximately two months.

${ }^{4}$ L.I. Conrad, 'The Pilgrim from Pest: Goldziher's Study Trip to the Near East (1873-74)', in I.R. Netton (ed.), Golden Roads: Migration, Pilgrimage and Travel in Medieval and Modern Islam (Richmond 1993), 93-137. 
since the report is a proper essay, it shall be sent for review'. ${ }^{5}$ It was indeed printed the same year, in the Academy's own series of essays, entitled Report on the Books Brought from the Orient for the Library of the Hungarian Academy of Sciences with Regard to the Conditions of the Printing Press in the Orient (henceforth the Report). ${ }^{6}$

It is possible that the text read in front of the audience and the printed essay are not entirely identical. A summary of the oral presentation mentions that Goldziher 'stressed that the man who first introduced the printing press in Muslim countries was a Hungarian'. This reference, probably to Ibrahim Müteferrika (1674-1745), does not figure in the printed text. The summary also adds that 'after the presenter had mentioned the official journal in Cairo and described various Arabic journals, among which Egypt, Syria and the North African principalities (regensségek) are represented, he shifted to [describe] the collection he made himself. ${ }^{7}$ There is, unfortunately, no such detailed description of Arabic journalism in the printed version. The manuscript of the Report is not among the papers of Goldziher at the Academy. ${ }^{8}$ The text here is the English translation of the printed Hungarian article.

\section{The Aims and Scope of the Report}

This is a report about the printed books Goldziher purchased for the Academy's library. It was written after his return to the AustroHungarian Empire. ${ }^{9}$ In general, he comments on Arabic printing and journalism. In particular, by describing the books and their importance, Goldziher gives an introduction to Muslim scholarship

5 'Tizenhetedik akadémiai ülés, az I.ső (nyelv- és széptudományi) osztály ötödik ülése,' in AzI. (nyelv-és széptudományi) osztály jegyzókönyvei (Budapest 1874), 15-16. Its manuscript is in 1488, MTARK.

${ }^{6}$ Goldziher Ignácz, Jelentés a Magyar Tudományos Akadémia Könyvtára számára a Keletröl hozott könyvekról tekintettel a nyomdaviszonyokra Keleten (Értekezések a Nyelv- és Széptudományok köréből, vol. IV) (Budapest 1874).

7 'Tizenhetedik akadémiai ülés, az I.ső (nyelv- és széptudományi) osztály ötödik ülése', A Magyar Tudományos Akadémia Értesitöje, 8 (1874), 103-4, MTARK.

${ }^{8}$ Information received gratefully from K. Dévényi, Curator of the Goldziher Correspondence in the Oriental Collection of MTA (henceforth GC).

9 The 28 Muharram 1291 (17 March 1874) issue of al-Waqā $i$ al-Misriyya had just reached Goldziher when he was writing the Report (on p. 10 in the original Hungarian essay, here p. 458). The exact date of writing, calculating a little delay and the approximate ten-day journey from Alexandria to Pest, would be the beginning of April. 
in Arabic. This text is a testament to what the twenty-four-year-old scholar thought basic for upgrading a specialized library in Arabic Studies. In addition, it reflects what he chose to tell to the mostly non-specialist Hungarian academics about scholarship in Arabic. Finally, as I argue below, Goldziher applied the Hungarian understanding of the connection between literature, language and nation to religious and scholarly texts in Arabic. His interpretation may unintentionally utilize religious texts for non-religious purposes. The Report in 1874 thus preserves a unique Orientalist interpretation of Arab national sentiment and its relation to Arabic texts.

\section{Goldziher's Hungarian and its Significance in the Report}

Despite B. Heller's judgement that Goldziher's Hungarian language is distinguished by its eloquence, ${ }^{10}$ the Report makes a difficult reading for the modern reader. Since this text is a report it lacks a consistent scholarly argument although it is logically composed. It is also possible that Goldziher was prevented by the death of his father in early May 1874 from paying full attention to the edited version and to polishing the language. ${ }^{11}$

The main reason is that Hungarian academic prose was in the making in the 1870s. The Academy's aim was to encourage scholarship in Hungarian (in contrast to the prevailing German). But since most scholars came from German-speaking environments, were educated in German universities, or their mother tongue was a version of German, the scientific terminology was full of Germanisms and Hungarianized Latin expressions. Goldziher was no exception. Despite three times referring to Hungarian as his mother tongue, once in this Report (p. 34 in the original Hungarian text, here p. 474 cf. its significance below), it may not have been so. I. Ormos states that Goldziher 'grew up multilingual' and his mother tongue was possibly 'a variety of German with Jewish features in it'. Ormos suggests that Goldziher considered Hungarian as his mother tongue out of patriotism thus it was his 'national language'. ${ }^{12}$ As to his level of Hungarian, G. Vaderna, an expert on nineteenth-century Hungarian

10 B. Heller, Bibliographie des oeuvres de Ignace Goldziher (Paris 1927), 1.

11 When Goldziher's father died on 4 May 1874, he kept vigil for days. Goldziher, Napló, 100.

12 I. Ormos, 'Goldziher's Mother Tongue - A Contribution to the Study of the Language Situation in Hungary in the Nineteenth Century', in É. Apor and I. Ormos (eds), Goldziher Memorial Conference (Budapest 2005), 203-43. 
literature, and who kindly double-checked this translation, expressed his opinion that Goldziher masters professionally the contemporary Hungarian academic prose in the Report. In some cases Goldziher clearly thinks in German (it is obvious in his explanation about the Book of Proverbs) but this mental set does not result in the incorrect use of grammar or vocabulary. ${ }^{13}$

It is often noted that Goldziher wrote the majority of his works in German. German was also the language of his diaries. Nonetheless, until the Report (between 1862 and 1874) Goldziher had published thirty-three Hungarian texts out of eighty-five writings (including reviews). ${ }^{14}$ This number may be modified; for instance, R. Simon remarks that Goldziher is said to have written his first significant book Mythology among the Hebrews originally in Hungarian (published in German as Mythos bei den Hebräern, 1876). ${ }^{15}$ Goldziher continued to publish in Hungarian; approximately a fourth of the life-oeuvre is in this language. What explains this commitment?

One reason, as Simon suggests, is that the young Goldziher was sent to study at Leipzig at the behest of Minister Baron J. Eötvös (1813-71) who saw great promise in him. Eötvös was a liberal Hungarianizer of public education and emancipator of Jews and Goldziher remained faithful to his deceased patron's ideas. ${ }^{16}$ Another reason, as Heller, ${ }^{17}$ Simon, ${ }^{18}$ Ormos and in particular Conrad explained, is that Goldziher used Hungarian predominantly to express his personal views on contemporary issues for a Hungarian readership (as opposed to his scholarly publications in German). ${ }^{19}$ In addition,

13 It is a great pleasure to express my gratitude here to G. Vaderna who patiently answered my queries and suggested some corrections in the final draft.

${ }_{14}$ Numbers compiled from Heller, Bibliographie, 17-72; 'Goldziher Ignácz irodalmi múveinek jegyzéke, összeállította több tanítványa’, in Keleti Tanulmányok - Goldziher Ignácz születésének hatvanadik évfordulójára írták tanitványai (Budapest 1910), 7-62; A. Scheiber, 'A Supplementary Bibliography of the Literary Work of Ignace Goldziher', in A. Scheiber and J. Somogyi (eds), Ignace Goldziher Memorial Volume (2 vols, Jerusalem 1958), 1:419-29; idem, 'Addenda to the Bibliography of Goldziher' in Ignace Goldziher Memorial Volume, 2:209-14; idem, 'Ergänzungen zur Bibliographie I. Goldzihers', in A. Scheiber (ed.), Ignaz Goldziher, Tagebuch (Leiden 1978), 331-4.

15 R. Simon, 'Bevezetés', in I. Goldziher, Az iszlám kultúrája - müvelödéstörténeti tanulmányok (2 vols, Budapest 1981), 1:74.

16 R. Simon, Ignác Goldziher - His Life and Scholarship as Reflected in his Works and Correspondence (Budapest 1986), 23-4.

17 Heller, Bibliographie, 265.

18 R. Simon, 'Bevezetés', in Goldziher, Az iszlám kultúrája, 1: 73-81.

19 Conrad, 'The Pilgrim from Pest', 94. 
Conrad remarks that at this time Goldziher was viewed by Hungarian linguists as the pupil of 'the swindler' Vámbéry, and he had to make an extra effort to establish himself on his own terms. ${ }^{20}$ The Report and its reading in the Academy's session was Goldziher's second rite de passage within higher Hungarian science. He hoped for a promised professorship. As is known, this effort was in vain.

\section{The Report in Context}

The text closest in time to the Report is a talk about contemporary Egypt, in the so-called Unió-egylet (Union Club) on 11 April 1874. This impassioned speech later appeared in print entitled 'Egyiptom új korszaka' ('The New Epoch of Egypt'). ${ }^{21}$ Next is the manuscript of his German Oriental Diary, with Hungarian, Arabic, Hebrew, Greek and Latin insertions, which was written intermittently from 23 September 1873 (published in 1987; it stops on 14 January 1874). In addition, Goldziher kept a notebook in Arabic (now lost) and possibly other smaller notes. ${ }^{22}$ He later quoted entries of February 1874 from a text he called Tagebuch thus either his Oriental Diary or his Arabic notebook covered possibly his full stay in Cairo. ${ }^{23} \mathrm{He}$ also sent letters in German and Hungarian to various journals during the journey. ${ }^{24}$

20 L.I. Conrad, 'The Dervish's Disciple: On the Personality and Intellectual Milieu of the Young Ignaz Goldziher', Journal of the Royal Asiatic Society of Great Britain and Ireland 2 (1990), 225-66, at 261.

${ }^{21}$ Dr I. Goldziher, 'Egyiptom új korszaka', Atheneum 6 (1874), 1090-8, $1154-$ 9, 1218-22.

22 Cf. R. Patai, Ignaz Goldziher and his Oriental Diary: A Translation and Psychological Portrait (Detroit 1987) and the critique of L.I. Conrad, 'The Near East Study Tour Diary of Ignaz Goldziher', Journal of the Royal Asiatic Society of Great Britain and Ireland, 1 (1990), 105-26.

23 Conrad argues (Conrad, 'The Near East Study Tour', 111-12) that Patai (Patai, Ignaz Goldziher, 26) is mistaken when he assumes that there was a second part of the diary which was destroyed. Conrad believes that Goldziher interrupted writing because he became too busy studying at al-Azhar. However, the references in I. Goldziher, 'Journalistik im Orient II', Pester Lloyd, 30 July 1874, to diaryentries in February 1874 in his Tagebuch may support Patai's supposition; or, as Conrad points out, we must suppose that these remarks are about the Arabic notebook (Notizbuch) which he called a diary (Tagebuch) in the Pester Lloyd.

${ }^{24}$ For a full list of these letters and other publications cf. footnote 6 in Conrad, 'The Dervish's Disciple'. 
The Hungarian text within the Report most referred to is his own essay On the Question of National Genealogy among the Arabs. ${ }^{25}$ This was a text that he read out in front of the Academy's First Section in 1873. In this essay, he deals with the contradiction between the universalism of Islam and Arab genealogy or Persian shu'übiyya. This was a problem Goldziher personally might have been deeply interested in: the question of race, descent and nation; behind the brilliant observations one may detect the personal dilemmas of a Hungarian Jew in the 1870s. By referring to On the Question of National Genealogy among the Arabs in the Report he thus provides the audience with an already known reference and establishes his reputation as a scholar in Hungarian. The remark about Hungarian as his mother tongue and the last sentences of the Report about scholarship and homeland also mirror this effort.

In terms of content some later texts reflect the journey, too. Of particular interest is an article in German in three parts, 'Journalistik im Orient', which might be the separate publication of the survey mentioned in the minutes of the Academy's session. ${ }^{26}$ In 1879, Goldziher published a Hungarian article about Muslim education, in which he described his experiences at al-Azhar (this was later incorporated into The Islam). A text on Muslim public opinion and journalism was also published in January 1882. ${ }^{27}$ These articles indicate that the topic of the Report - Arabic printing and its political significance - remained with Goldziher for several years. He may have followed an earlier model of Orientalist tropes about Arabic printing. ${ }^{28}$

Goldziher did not finish purchasing books when he left Cairo. One reason is that not all volumes of the multi-volume titles were available at the time of his stay. For instance, he could purchase only three of the five volumes of Täj al-'Arūs. Goldziher thus entrusted the private printer G. Castelli to buy some of the missing ones and also new books. Castelli in November 1874 sent a letter in Arabic to Goldziher mentioning that even at that time the thirty-first volume of 'Antar was nowhere to be found (the Report indicates thirty-two

25 I. Goldziher, A nemzetiségi kérdés az araboknál (Budapest 1873).

26 I. Goldziher, 'Journalistik im Orient', Pester Lloyd, 29-30-31 July 1874.

27 I. Goldziher, 'A mohamedán közvéleményről', Budapesti Szemle, 30 (1882), 234-65, translated as 'Muhammadan Public Opinion' by J. Payne and P. Sadgrove, JSS 38:1 (1993), 97-133.

${ }^{28} \mathrm{I}$ am grateful to K. Schwartz for a last minute reading of the final draft. 
volumes of 'Antar). ${ }^{29}$ Goldziher also commissioned H. Gharzūzī in Alexandria to subscribe to al-Waqā $\ddot{i}$ al-Misriyya and al-Jawä $\vec{i} b$ in his name. ${ }^{30}$ And naturally he continued to be interested in Arabic printing and to buy books for himself in the next decades, as his correspondence amply testifies.

\section{The Books}

From the sources mentioned it is clear that during his journey Goldziher visited bookshops, printing presses and their owners in Beirut, Damascus, Jerusalem and Cairo but possibly bought books for the Academy's Library only in Cairo. In this regard, this acquisition is a forgotten late chapter in the development of the so-called 'Islamic library collections' in Europe. ${ }^{31}$ Goldziher acquired exactly one hundred volumes (kötet). Some books contain two or three titles printed on the margins, thus one 'volume' may mean as many as three distinct titles in one copy. Goldziher mentions approximately forty titles in the report. Some titles were published in several volumes. If Goldziher meant one hundred volumes then his report must have incorporated almost all titles since, for instance, Fatāw $\bar{a}$ Q $\bar{a} d \bar{\imath}$ Khān was printed in four, Kitāb al-Aghān̄ in twenty, and Qișsat 'Antar in thirty-two volumes. I could not locate a list of the books among the papers of the Academy.

Indeed, establishing a precise list is almost impossible. The old Registry (Iktatókönyv) in the Oriental Collection should contain all the titles but it is not chronological and there is no indication of provenance (although some books contain an identifying mark). The Academy's library, as Goldziher remarks, had already had a collection of books and manuscripts in Arabic. Also, in Cairo Goldziher may have bought books printed in Beirut, Malta, Istanbul or Paris, and thus any identification based only on Cairo-provenance may be proven to be false. In addition, the Registry may reflect a slightly later

29 Letter dated 20 Shawwāl 1291 (30 November 1874), from G. Castelli to Goldziher, in GC. Castelli adds that the book al-'Iqd al-farìd is also not yet available. I am grateful to K. Dévényi for calling my attention to this letter.

30 Subscription form of $a l-J a w \bar{a} i b$, signed by Habīb Gharzūzī, dated 1 Muharram 1291 (18 February 1874), in GC. Cf. also Napló, and 'Journalistik im Orient'.

31 S. Roman, The Development of Islamic Library Collections in Western Europe and North America (London 1990). Roman, as the title indicates, leaves out the Habsburg (later Austro-Hungarian) Empire completely (though not Italy). 
state of the collection. For instance, 'Antar is registered fully but we know that Goldziher could not find one volume in 1874 .

Goldziher's Report is about books that would help the development of Arabic Studies in Budapest. He is very conscious of the fact that he has done a great service to the Academy and in general to Hungarian scholarship. Though first he mentions 'our collection of dictionaries' (p. 27 in the original Hungarian, here p. 470), later he switches to 'your linguistic collection' (p. 29 in the original Hungarian, here p. 471) or 'your library' (p. 35 in the original Hungarian, here p. 475). The emphasis on the service, embodied by the books, may indicate his hope that this would boost his chances for the university position. It is also possible that during the presentation at the Academy his reference to books 'in front of us' is not a rhetorical device but he may have shown the book in question in order to give further proof of his commitment. If this analysis is sound, then this Report is a hitherto unacknowledged milestone in his early quest to be accepted by the Hungarian academy.

\section{Comments on the English Translation}

I have changed the transliteration of all Arabic expressions, including personal names, to match JSS conventions. The names of the Ottoman Egyptian governors have been also transliterated as Arabic names, because Goldziher gives them as such (Muhammad 'Alī, not Mehmet Ali). Some corrections have been made (Ferg'āni to al-Farghānī, Abū Su ūd to Abu'l-Su ūd, etc). The original text retains the letter 'd)' on pages 25 and 34 at the beginning of a new section, but there is no other sign for numbering. These are deleted in the translation.

I have tried to preserve some elements of Goldziher's ironic and witty style. But I have always opted for clarity at the expense of poetics or humour. The book-titles are given in their now standard translations (for instance, Goldziher translates Mafätih al-Ghayb to Hungarian as Keys of the Secret but its accepted English translation today is Keys to the Unknown). There are some problematic expressions. The word izlés, 'taste', is often used and so translated in the sense of 'education', 'habit', 'logic' or 'custom'. Muhamedán has been translated as 'Muslim'; hagyomány, 'Tradition', has always been written with a capital $\mathrm{T}$ when Goldziher refers to hadith in general; and what Goldziher calls ritus, 'rite', has been rendered as 'legal school' (mälikì, etc.). Some abbreviations are written fully (al-Gh. = al-Ghazālī). 
Goldziher's references in the footnotes have been changed according to JSS conventions, and full bibliographical data have been given, but without his indications of book-proportions (folio, octavio, etc.). All footnotes are Goldziher's. The translator's remarks are in square brackets. The paragraphing of the original has been retained.

\section{Translating Literature and Nation in the Report}

Lastly, a particular problem must be singled out. This is the translation of the Hungarian word irodalom which today means 'literature'. Goldziher generally uses this word in the widest possible sense, that is, anything written in Arabic (for instance, p. 6 in the original Hungarian, here p. 455). Literature in his use is often a higher category than adab. Thus I have often omitted it or translated it as 'corpus' but where I judged significant, I kept 'literature'. Sometimes it carries the meaning of 'scholarship', or rarely, in today's usage, belles-lettres. The expression irodalmi irály has been translated as 'style' or 'scholarly agenda', while in some cases it has been omitted.

Goldziher's use of irodalom demonstrates the application of the nineteenth-century Hungarian and German understanding of literature as an expression of national identity to Arabic texts. Its central element is the connection between (written) language and the imagined nation. Therefore at this general level of language there is no distinction between humanities - Geisteswissenschaften - and belleslettres. Language is a common and legitimate domain of linguists and writers or poets who are all masters of the national imagination. This is perfectly reflected in the division of the Hungarian Academy where Goldziher presented the Report: 'Linguistics and Literary Scholarship'. Apart from this consequence of re-merging the separated and institutionalized spheres of human knowledge, the concept of national literature stands in opposition to religious texts. Thus, when all texts count as national literature, the mediaeval religious and scholarly spiritual interpretations gain a non-religious context (the nation). Goldziher applied this general understanding to (the printed) Arabic writings.

This is the reason why nemzeti, 'national', is generally an attribute of any Arabic written account in his Report. It is clear that Goldziher understands national sentiment in Egypt as an Arab and not as a territorial Egyptian political identity. Thus national is often omitted or translated as Arab. A telling remark is on page 6 in the original Hungarian text (here p. 455). Here Goldziher - after criticizing the 
Arabic translations of French works - emphasizes that the printing press is the main instrument to 'awake the public interest in the sciences and literature', more precisely, 'national literature'. This small comment clarifies that in his understanding all Arabic texts are effectively national texts. And more: the great medieval Arabic corpus is a national one, belonging to the Arab nation in the present, which, according to him, must be disseminated through the printing press in order to help progress. In Goldziher's eyes, the medieval Arabic texts preserve the essence of the nation (although he also praises the great nineteenth-century writer Ahmad Fāris Shidyāq). Printing, as a time machine, brings the works of the past into the present. Such an understanding may have also something in common with the ideas of the thinker Jamāl al-Dīn al-Afghānī (1838-97) and his Cairo-circle with whom Goldziher was in touch in early 1874. Presenting his Report about the printed books, the young Goldziher in 1874 thus provides his ideal canon of the Arabic national corpus, using the liberal technique of constructing the nation in literature.

\section{(Page 3)}

\section{REPORT ON THE BOOKS BROUGHT FROM THE ORIENT FOR THE LIBRARY OF THE HUNGARIAN ACADEMY OF SCIENCES WITH REGARD TO THE CONDITIONS OF THE PRINTING PRESS IN THE ORIENT}

\section{DR IGNÁC GOLDZIHER}

(Read at the 20 April 1874 session of the Hungarian Academy of Sciences)

First of all, when I gratefully report to the Honourable Department of the Academy on those Arabic works which I acquired in the Cairo book market, on behalf of the Library of the Academy, from the sum that was given for that purpose, I have to make some remarks about the criteria that guided me in the compilation of this small book-collection whose selection was entrusted to me. To begin with, the task was not to add so-called library pieces', that is, rarities and unique books, to a collection which is fullyequipped with all the essentials, but to place those best known authors and scholarly tools within a collection-in-the-making which are crucial in order that an Orientalist in Budapest may not starve in the absence of 'everyday bread'. During the compilation of this little collection, apart from the present state of the Library of the Academy in this regard, I also took into 
consideration the basic works which are in another public library of the capital and in the private libraries of some colleagues (as far as I could know these), so that the private and public collections together would fulfil the critical needs whose satisfaction, until now, has been only talked about.

Thus it is easy to understand, partly following from the reasons above, why I had to ignore (Page 4) manuscripts. Really valuable and useful manuscripts are increasingly rare in the Arab book markets because European bibliophiles have slowly migrated them to the huge collections of Europe. Thus we should look for the manuscripts of scholarly significance - at least the Arabic ones - in the British Museum or the Indian Office in London, in the Bodleian in Oxford, in the Refaiya in Leipzig, in the Legatum Warnerianum in Leiden, or in the Sprenger-Wetzstein- and Petermanncollections in Berlin rather than where they had originated from. The energy of the European lust for knowledge, coupled with financial sacrifice, wiped the most ancient and most important sources of Arabic philology and Muslim science of religion out from their original homeland to [Europe] where these studies have found a new home in the last decades. Not considering this [circumstance], another obstacle eliminated the collection of manuscripts from my agenda.

Muslims at first regarded with terrified distrust all inventions which arrived from Europe and which are now used in their lands as well including the steam-locomotive and the telegraph. I heard that when in Damascus the telegraph was first introduced a great debate took place among the scholars of religion whether a Muslim true believer can use this innovation, until by the skin of their teeth the scholars found a tradition upon which they could permit this bid'a. They call bid'a all innovations that the Prophet could not know and did not use. Some, like the Wahhābi or some North-African communities, apply the notion of bid'a even to smoking, while the Syrians - not out of devotion to the consequences of applying the religious concept though quite characteristically — call bid' $a$ the paper-cigars, which have been in use for a decade, in contrast to the pipe and the narghile. Thus, when the introduction of the printing press was first discussed, naturally the 'Pharisees and scripturists' at once brought the objection that such a Frankish innovation (Page 5) would be the fattest $b_{i d} a$. They wanted to stop the import of typography to their countries with a mighty quod non. And one more obstacle was added to this. There is no Muslim book in which the word Allāh could be avoided. It is known that a Muslim author must start all books or decrees with this sentence: 'In the name of Allah, the Compassionate and Merciful.' A tradition says 'Every important thing which does not start with mentioning Alläh shall dissolve' (kullu amrin dhì bālin là yubtada'u bi-dhikri'llāhi fa-buwa qātìiun). In addition, it is quite hard not to find a citation from the Qur'ān in a book written by a Muslim, or if not a direct quotation, at least paraphrases from the Sacred Book. This is a feature of the Muslim style; the later Hebrew socalled 'musiv style' does the same with the phrases of the Old Testament. 
The pious Muslim consciousness thus was harassed whether the printing tools or the paper itself could be guarded against things which are incompatible with the dignity of the books which contain the name and word of God at every turn. They were especially reluctant to receive the printing press enthusiastically since the name and word of Alläh was printed on the paper by a brush composed of hogs' hair — such was their attitude at first. ${ }^{32}$ Slowly, however, as all other preconceptions, this [distrust] was also defeated, and among others the famous state printing house was established in that part of Cairo which is known as Būlāq. Only the printing of the Qur'ān was prohibited, which has been in effect until today in Egypt. The press was established by Muhammad 'Alī Pasha — the Governor — with the aim of printing books in the arts of the army and war, and some tasteless Arabic translations of French works, which are, by the way, absolutely unnecessary in Egypt. This was indeed done but the reading public (Page 6) had not much appetite for the expensive typographic products of the state printing house. Reading about military issues is not quite pleasant and amusing to everyone; and French literature is so much the exact opposite of everything what the Arab reader needs and would read with interest that serving such exotics to a people who can boast of the most beautiful literature discloses the total misunderstanding of their spirit. If someone wants to know whether the first products of the printing press in Būlāq sold like hot potatoes, one should have a look in the library which is located in a state-owned building on a street of Cairo, called Darb al-Jamāmīz. The walls of a room, which is occupied by the officials of the library, are completely covered with huge shelves which are full with these yawning products, awaiting the customers for twenty years [Goldziher is mistaken. If these were the earliest products of Būlāq, at least forty years had passed by 1874]. Muhammad 'Alī, this real 'generalissimo bum-bum', had so little education and sensitivity for the unique literature of his own subjects, that it did not occur to him that it would be better to disseminate their corpus through those hog-haired brushes than bad translations of hopeless French literary pearls. For sure, the translated works were selected quite fancifully. I do not believe that the dreadful hog-haired brushes frightened the Pasha (who loved to be seen as liberal) when he left the works of the true believers in manuscript despite the excellent occasion for their distribution. Only a few such works appeared from Būlāq in the first period of the press. The successors of Muhammad 'Alī were even less enthusiastic about the press. 'Abbās Pasha wanted to get rid of most educational establishments of the first storming Egyptian viceroy. As I heard, this institution [the press] was given over half-gratis to Rushdī Bey, though in earnest it is destined to awake the public interest in scholarship and literature - i.e. national literature. During this second

32 E.W. Lane, An Account of the Manners and Customs of the Modern Egyptians (2 vols, London 1871), 1:355. [Goldziher almost verbatim translates Lane into Hungarian, thus I have used Lane's words translating back to English.] 
period of the press, the guiding principle was profiteering speculation rather than the principle of public interest, which should be connected to such an institution. But even so, this profiteering stimulus (Page 7) had to conform to the taste of the scholarly and lay public; thus domestic writings were included in some measure. Ismāîl Pasha, the reigning viceroy-governor, bought the press from Rushdi back to his possession, thereby he almost cleaned the spot from the face of his dynasty, splotched by his predecessor for giving it away. Thus where previously were the words 'Printed in the press of Rushdī Bey', now we can read the words 'Printed in the Būlāq press of the Khedive'. It is interesting that this establishment in Būlāq is not called a 'state' institution. To understand this, we have to bear in mind that state institutions in Egypt generally are parts of this or that prince's dä'ira which means that the income of the institution goes to the prince's apanage. The press in Būlāq was given to an infant Pasha as his dä ira and his officials handle its income for the Pasha. As a result, we look in vain for the products of the press in the magnificent public Arab library (another state institution) which was established by the zealous 'Alī Pasha Mubārak, the ex-education chief, together with the always eager Sayyid Bey Șālih al-Majdī, with such a mastery and care for the scholarly public and for everyone who wants to acquire knowledge in Arabic texts. In this way, there is no such connection between the state library and the state press which in Europe leads to legal deposit copies. On the other hand, for us it is quite hard to understand the hardships that await even the best expert in following the work and products of the press. The announcements and catalogues are so imperfect, unsystematic and poorly compiled that they are more confusing than informative.

But now the press works very diligently and properly, extending its activity to all branches of Arabic scholarship. It has a profound good taste in selection. One can say that it has already rendered a great service to Orientalist scholarship, since we now not only possess the most important works of Muslim theology in very beautiful editions but the rare basic works and sources of (Page 8) the more narrowly understood Arabic philology and history have become also accessible through the press. They pay attention to the accuracy of the publications - which is, in the case of Oriental books, always a little hard to achieve - by employing some experts of Arabic philology as correctors. I would like to mention only two names of the correctors who worked in Būlāq: Aḥmad Fāris and Naṣr al-Hūrīnī. The best one, who is at the moment the very knowledgeable editor of al-Jawä'ib in Constantinople (an excellent Arabic weekly) is respected by everyone as the first master of national philology. The second one is less celebrated but a very meritorious person and we cannot find a more diligent and expert scholar in handling Arabic texts. One of his remarkable essays is closely related to the press in Būlāq. Since there are many issues of Arabic orthography about which grammarians do not agree and did not work out a clearly defined rule, and since even the most practiced grammarians may commit mistakes against the spelling rules, this corrector of the Būlāq press, 
especially with regard to printing, wrote a very pretty work about Arabic writing and rules of orthography; one cannot find a better and more authentic compilation and explanation. ${ }^{33}$ Therefore we may say confidently that concerning the quantity of production, the quality of the selected works, their execution, and their accuracy, it is the first among the press houses focusing on Arabic literature. It must be noted, however, that typography in Arabic has been considerably improved, partly unconnected with the Būlāq institution (as is the case everywhere in India), partly following its example. Not considering the presses in monasteries (which we cannot list here) and lithography, which is very popular everywhere in the East, I want to mention only the excellent typographical institutions in Beirut in Syria, and the private presses in Tunis and Cairo ${ }^{34}$ (Page 9) which are equally diligent in their work. All these printing presses, and especially the one in Būlāq, have earned many merits by printing both the rare and the more accessible manuscripts. Thus the manuscripts - as far as the content of the texts is concerned - became superfluous and now are only important for textual criticism. Oriental studies in Europe would benefit from this useful activity of the Cairo press year by year, had there been any connection between this press and our scholarly public. But in Egypt they care little about this; we do not even know about their printed products, although everyone who deals here with such things would benefit. On the other hand, we have to regard with appreciation the way in Cairo the advice and wishes of European scholars are respected concerning the material to be published. When the Viceroy heard about the assertion of Professor Fleischer, the charming Nestor of contemporary Orientalists, that if Sïbawayhï’s great basic work in grammar - of which the public library possesses beautiful manuscripts - would be printed this would serve both the glory of Būlāq and the benefit of Arabists, the order was immediately issued to start its publication using the library funds. Thus the press in Būlāq fills gaps in two fields. First, it satisfies the reading public that deals with the narrowly defined Muslim scholarship of religion, by publishing the basic works of

33 Nașr al-Wafā̄i al-Hūrīnī, al-Mațāli al-Nașriyya li'l-Matābi al-Mișriyya fi'lUșul al-Khattiyya (Cairo 1872).

${ }^{34}$ Beside the state printing press I have to mention the so-called 'school press' (matba'at al-madāris) which supplies the schools with the necessary textbooks; it publishes an educational review, entitled Rawdat al-Madāris. At this moment, the private presses in Cairo are the following: a) the Castelli-press b) the press of Wād $\bar{\imath}$ al-Nīl whose owner is Abu'l-Su'ūd Effendi c) the press of Musțafā Wahbī Effendi, which, since the exile of 'Arifī Pasha — for reasons I mention later — nowadays barely survives. There existed the Shāhin printing house whose product was the entire 'Antar edition that I have purchased for the Library of the Academy. But this institution has ceased to exist. The presses of Beirut and Tunis are not really concerned with the distribution of the old corpus but rather with the publication of living Arab writers' works. 
exegesis, Tradition (Page 10) and other theological branches. In this regard, I have to add immediately that old-fashioned sheikhs still prefer manuscripts, even in these days of the printing press. I have never seen in the hands of the sheikhs of al-Azhar other than manuscripts when lecturing, while we students followed the old scholars' wise explanation from the printed versions. Secondly, just as the Oriental scholar who deals with the sciences of religion may have access to belles-lettres or history besides religion, his European colleagues also gain access to even the rarest pearls of old Arabic belles lettres, thus [printing] enriched us with the most valuable sources.

At the moment I am writing these lines I have received the latest bulletin of the state press in Būlāq, ${ }^{35}$ advertising that in the coming weeks a work as famous as it is huge and as rare as valuable, called al-' Iqd al-Farid, is about to be printed. This is the same work from which I took a large part of the lecture that I read in this place one and a half years ago ${ }^{36}$ and for which a manuscript in Vienna was the primary source. With the Egyptian edition of this treasury of sources they render a service to Oriental literature and history. Those who felt so sorry about the rarity and unpublished nature of this important work will evaluate [this service] highly.

According to Muslim custom — and this custom became a rule — books can be only arranged in the following order. The Qur'ān must come always on the top of the whole pile, and under the Sacred Book, according to a strict hierarchy, first exegetic books, then the Tradition, legal - i.e. canonlaw -, lexical, grammatical, poetical, the so-called cultured works, and finally the historical books which are also within adab (cultivated knowledge). Every time I bought a book from a Muslim concerning his religion (not every one of them would (Page 11) sell such works to a kâfir), he made it my duty to handle and use the sacred books with the respect which is due to them. I am confident that my distant friends would be satisfied if they knew that even now, on this occasion, I present the intellectual works of their scholars according to the order in which they themselves would arrange them, one above the other. The Muslim library thus consists of books on the top of each other, not next to each other: the books are not standing but lying. After this explanation, let me single out the most important members of the collection which I have compiled. It consists of one hundred volumes exactly.

It is known that the basis of all Muslim religious sciences is the explanation of the Qur'ān (al-tafsīr). These Qur'ān explanations study the basis of Islam from a linguistic, from a theosophical and from the Tradition's point of view. ${ }^{37}$ Al-Baghawī, al-Zamakhsharī, al-Bayḍāwī, Muhyè al-Dīn ibn

35 al-Waqā̄i al-Misriyya, n. 549 (28 Muharram 1291, 17 March 1874).

36 I. Goldziher, A nemzetiségi kérdés az araboknál (Budapest 1873), 49-62.

37 We have an educated critique of Qur'ān scholars and their explanations in a work of al-Suyūțī, Tabaqāt al-Mufassirīn, which was published by a Dutch scholar: 
'Arabī, all of them contributed with their own view on the study of the Sacred Book. The one who approached it from the most diverse aspects and thus his explanations and conclusions became the encyclopaedia of Muslim religious scholarship was Fakhr al-Dīn al-Rāzì (d. AH 606) in his great work which is entitled Keys to the Unknown (Mafätīh al-ghayb) and which is usually called The Great Commentary (al-Tafsì al-Kabir $).{ }^{38}$ An example of how widely al-Rāzì conceived the field and task of the exegete is known from his statement that he could have elaborated ten thousand questions based only on the few words in the first verse of the Qur'ān $(F \overline{a t} i \grave{b}) .{ }^{39} \mathrm{He}$ did not discuss these ten thousand questions neither in this huge work, nor in the two-volume commentary which, according to the bibliography writers, (Page 12) he devoted only to the first seven sentences of the Qur'ān. ${ }^{40}$ However, if we open the eight heavy volumes of al-Rāzī's exegetical work, we recognize immediately the amazing many-sidedness - I may say allsidedness - and the imaginative taste with which the author of this famous work studies something which is in itself so simple as the Qur'ān. And if we consider that al-Rāzī is one of the pillars of that Muslim science of religion which is usually called kalām and which is mostly identical with what we call the philosophy of religion, and that the author considers all opinions which opposed his own, such as those of the mu'tazila, the shía, etc., in all questions of this branch of scholarship, we can easily recognize that this work is one of the main sources for the study of ash'ari dogma and philosophy.

The Oriental presses have the very peculiar feature that they do not waste the margins of the book (al-hamish). In this regard they might be comparable to the medieval copyists in Europe. It is very rare to find an Eastern print with any size of margin which is not used. Either we find there critical or explanatory notes concerning the main text or, if the main text is a commentary (sharh, häshiyya), the text which is commented upon (matn) is printed in the margins. If there is no possibility of doing this, they often place a book in the margins which has nothing or very little to do with the main text. The copies of Sa'dì's Gulistān, printed in Persia, usually contain in the margins another work from the same author, the Bustān, and we will soon meet another historical work within this report whose margins contain three other books. At the moment when I left Cairo the Būlāq-press had just started a huge work, planned for ten volumes, which may illustrate the above-mentioned typographical tradition: they want to publish the commentary of al-Qasțallānī (Page 13) on al-Bukhārī’s great collection of

\footnotetext{
A. Meursinge (ed.), Sojutii Liber de Interpretibus Korani (Lugdoni Batavorum [Leiden] 1839).

38 F. Wüstenfeld (ed.), Ibn Challikani Vitae Illustrium Virorum (Göttingen 1835), 6, 133.

39 G. Flügel (ed.), Haji Khalfae Lexicon Encyclopaedicum et Bibliographicum (6 vols, Leipzig 1835-58). Cf. Meursinge, Sojutii, 14.

40 Flügel (ed.), Haji Khalfae, 2:574, nr. 3356.
} 
traditions in a great folio edition. They plan this edition in such a way that in the margins Muslim's similar work and a lengthy commentary (al-Nawawī) will be printed. We must note that only this latter work is a five-volume folio [already] in the Library of the Academy.

This is the explanation why in the margins of al-Rāzì's Keys to the Unknown we have another exegesis of the Qur'ān whose author is Abu'lSu' ūd and who is far from being as talkative as the famous writer whose margins he occupies.

If al-Rāzî's great work is a perfect source for the internal explanation of the Qur'ān, the one-volume book I would like to mention in the second place is the noblest product of general exegesis, or, as they say, of exegetical introduction. It is Jalāl al-Dīn al-Suyūțî̀'s al-Itquān fì-'Ulūm al-Qur'ān. I know only one essay comparable to this work in Arabic whose author is someone called Ibn 'Adìl. This latter's work has not gained currency; I know of only one manuscript and this I came across in the huge library of the famous 'Abd al-Khāliq Shaykh al-Sādāt. For those who know the History of the Qur'an by Nöldeke ${ }^{41}$ it is enough if I characterise al-Suyūtị's work as falling in the same category, but is written by a Muslim — and not for a prize.

Al-Suyūțī makes an effort to introduce method into the discussion of the sciences of Islam, and, to some extent, to establish a critical attitude in scholarship. Such a technique within scholarship was only present in connection with Tradition, by which scholars could rise above the material, discussing all preliminary questions that are important for a reasonable treatment of the Tradition. Muslim, who died in AH 261, had already written a methodological preface to his collection of traditions. Al-Suyūțī's programme was similar. He raised lexicography and exegesis (Page 14) to the highest level of his ideal of scholarship by such isagogia. ${ }^{42}$ As to lexicography, he met this aim in an epoch-making book. Kitāb al-Muzhir really encompasses everything. It contains all questions that an introduction into linguistics should contain; of course, at the contemporary level of scholarship. ${ }^{43}$ As to the introduction into the exegesis of the Qur'ān, it is that book which prompted this short discussion in the Itqān. Al-Suyūṭi was especially suitable to prepare such an exegetic encyclopaedia because of his great knowledge and because he was widely read. In addition, he loved truth which in many cases helped him to avoid the ridiculous and fabulous stories from which even such a faithful Muslim as our author turns away although by his time similar tales had already been canonized. ${ }^{44}$ It is natural

41 Th. Nöldeke, Geschichte des Korans (Göttingen 1860).

42 I have discussed the scholarly merit and significance of al-Suyūtīi in an essay entitled 'Zur Charakteristik as-Sujūti's und seiner literarischen Thätigkeit', Sitzungsberichte der Philosophisch-Historischen Classe der Kaiserlichen Akademie der Wissenschaften, Heft 8 (1871), 7-28.

43 Al-Suyūțī, al-Muzhir fì-'Ulūm al-Lugha (2 vols, Cairo 1282/1865-6).

${ }^{44}$ Cf. Nöldeke, Geschichte des Korans, XXXI. 
that in this work the author starts with the doctrines of the Qur'ān which form the basis of all true believers' faith. Yet it is undeniable that his judgement is still more reliable and healthier concerning the Tradition than any other Muslim author, even within the chains of such dogmatic principles. Our edition is the folio print made in Cairo ( $\mathrm{AH} 1279$ ) that I estimate higher than the Calcutta edition started in 1849 or the one which was printed in the Bibliotheca Indica. ${ }^{45}$

Now, according to the convention of my Arab friends, Tradition should follow. It is the collective compilations of those sentences which Muslims trace back to the Prophet himself, the founder of this religion. In the fact that such collections still lay in front of us we can understand that the socalled conservative spirit is doomed to failure in the face of the progress which penetrates all circles of the (Page 15) intellectual and material world. There is no phenomenon in this world with which conservatism - the most rigid and the most stubborn conservatism - would have made a more committed alliance than with Islam. This conservatism not only rules the theory of theology in their countries but it also forms the basis of the common folk's world view. This was evident already from those remarks which we have made about the concept of bid'a. And still, if we survey the history of Muslim culture, we find that there is no age in which there would not be a new idea born and by this new idea a small change in the worldview of this people or a new institution in their society would not have followed. Tradition was not allowed to be recorded in writing; it was only for oral dissemination. ${ }^{46}$ And we find Mālik b. Anas, already in the ninth decade after the hijra, collecting the material of Tradition after the verification of every single sentence. This verification of Tradition sentences is the only critical method with which we meet in Muslim religious scholarship. It is nothing else than screening every single authority through whose lips the sentence in question went through, from the Prophet to the authority who actually collects it (isna $\bar{a})$, and according to its flimsiness or [unbroken] continuity, the chain of tradition is categorized into grades of authenticity. The establishment of the right grade and its application entails, in fact, the critique of Tradition.

The collection of traditions was not as easy as we would think at first sight since these were known only orally. We read in al-Sha rānī that the pious men who collected Tradition sometimes travelled the four corners of the world in order to gain knowledge of every single tradition. ${ }^{47}$ Two men

45 M.W. Sadeedood-Deen Khán et al. (eds), Soyuti’s Itqán on the Exegetic Sciences of the Qoran (Calcutta 1857), with an analysis by Dr A. Sprenger.

46 Cf. Alois Sprenger's essay, 'Über des traditionswesen bei den Arabern', Zeitschrift der Deutschen Morgenländischen Gesellschaft 10 (1856), 1-17, at 5.

${ }^{47}$ Mizān al-Haqq (Cairo), p. 73. [I have not found such book. Goldziher possibly alludes to 'Abd al-Wahhāb b. Ahmmad al-Sha' rānī, Kitāb al-Mìzān (Cairo 1279/1862-3).] All distinguished collectors of Tradition are listed, with their biographies, in al-Dhahabīs Kitāb Tabaqāt al-Huffäz, which was published in a 
finished this task: (Page 16) al-Bukhārī (d. AH 256) and Muslim (d. AH 251). It is remarkable that though Muslim scholars agree that those traditions are the most authentic and, regarding the $i s n \bar{a} d$, possess the most direct continuity which were transmitted by the men of Arabia proper, ${ }^{48}$ still non-Arabs (in terms of origins) in the non-Arab provinces were the best and most famous developers of the science of hadith. This is really a remarkable fact which not only exists in this branch of Muslim scholarship but is also observable in all branches, including philology. ${ }^{49}$ Concerning the knowledge of Tradition it is said in particular that 'four are outstanding among all scholars in the world: Abū Zara'ā from Rey, Muslim from Nisāpūr, Dārimī from Samarkand, and' a man whose origin is recognizable from his name, 'al-Bukhārī from Bukhara'. ${ }^{50}$ Yet even this last one, who has been regarded as the best pillar of the science of Tradition until today, could only prepare for his task in Mecca. He set himself the task of compiling the most authentic traditions among the believers of Islam and of verifying the authenticity of each by the most precise isnād. Bukhāri knew how great the implications of this enterprise were and what problems he was prepared to solve, because such a work was destined to become the second most important authority, next to the Qur'ān, for all believers, both in dogmatic theology and in rituals. This pious man of Bukhara - as his biographers say - knew this importance and thus 'made the ritual ablution and prayed two rak' $a$ ' before writing down each and every tradition. To gain an insight into how carefully al-Bukhārī examined the collected traditions, it is enough to mention that out of the 600,000 sayings with which he became acquainted he declared only 7,275 authentic and worthy (Page 17) of inclusion in his book. ${ }^{51}$ This is why he called his book Jami al-Sahinh, that is, the collection of the healthy (the authentic) traditions. After the Qur'ān, this is the work upon which all religious practices and dogmatic content of orthodox Islam are built. The printing press in Būlāq has published this work several times; both the single text and with commentaries. We in Europe usually use the edition of Krehl (only the text), ${ }^{52}$ but unfortunately this beautiful edition has been awaiting its last fourth volume for six years.

lithographic edition by the tireless H.F. Wüstenfeld (ed.), Kitāb Tabaqāt al-Huffāz - Liber Classium Virorum qui Korani et traditionum cognitione excelluerunt, auctore Abu Abdalla Dahabio, in epitomen coegit et continuavit Anonymus (Gottingae 1833).

${ }^{48}$ Ibn Khaldūn (in his History, vol. 1) calls the hijäzi method the most serious (amtan) concerning its correctness.

49 Goldziher, A nemzetiségi kérdés, 14.

50 [Wüstenfeld (ed.),] al-Dhahabī, Kitāb Tabaqāt al-Huffāz, 42 (IX. nr. 34).

51 Cf. L. Krehl, 'Über den Sahih des Buchari', Zeitschrift der Deutschen Morgenländischen Gesellschaft 4 (1850), 1-32, where the academic author describes everything about the structure of this work.

52 L. Krehl (ed.), Le Receuil des traditions mahométanes par Abou Abdallah Mohamed Ibn Ismail el-Bokhari (3 vols, Leiden 1862-8) [vol. 4 was published by Th.W. Juynboll (Leiden 1908)]. 
Muslim, Bukhārî’s contemporary, collected traditions with similar aims and under a similar title. While Bukhārī often repeats the same sentence in various chapters (the Sahin is structured in thematic chapters), Muslim avoids repetition. In general, my experience is that Muslim is much more conscious and systemic than his venerated contemporary colleague. And Muslim masters his subject better and has gathered more material than Bukhārī. This is clear from the fact that he starts his work with a methodological and critical introduction which contains very valuable information. I believe that the five folio volumes in our small collection, which provide Muslim's text together with a precious commentary, are very useful for someone dealing with Islam. ${ }^{53}$ The author of the commentary is Abū Zakariyya Yahyā al-Nawawi (d. AH 676) ${ }^{54}$ who is a man of many merits in the science of Tradition, and whose other work - which treats the proper names in the traditions biographically — was started to be published by Wüstenfeld. ${ }^{55}$ One cannot wish (Page 18) for a more clear and useful work in this field than this commentary. Apart from his useful exegesis the work is distinguished by the fact that he tackles each tradition in a small monograph in which he explains the various opinions concerning the tradition in question, with such clarity and such logic, that no one would find it useless who wants to deal with problems of Islam in a historical way. Nawawī's commentary to Muslim is better for a European scholar than al-Qasțallānī's to al-Bukhārī. Of course, I would not say something like this in front of a Muslim scholar since these people worship al-Bukhārī with such a respect that you cannot name a better author than he and his commentators. Ibn Khaldūn says that followers of the Mālikī school preferred Muslim to Bukhārī but in my experience with my Mālikī friends this is not the case today. It must be said that the Muslim theologian world is gradually getting closer to recognizing the two Sahīhs on equal footing. This development has a lot to do with the fact that since the book was printed, they gradually know Muslim better and deal with his work more. I have experienced the same concerning other works of Tradition, especially the one which starts the project of collecting traditions: al-Muwatța' of Mālik b. Anas, ${ }^{56}$ and also

53 Sharh Muhyī al-Dīn Yahyā al-Nawawì áā Saḥ̄h Muslim (Cairo 1284/1867$8)$. There is another pretty Cairo edition of Muslim's text in two volumes and there is also a Calcutta edition (1265/1248-9) which was left out by Zenker from his Bibliotheca Orientalis.

${ }^{4}$ His biography was written by F. Wüstenfeld, Über das Leben und die Schriften des Scheich Abu Zakarija Jahja el-Nawawi, nach handschriftlichen Quellen (Göttingen 1849).

55 F. Wüstenfeld (ed.), The Biographical Dictionary of Illustrious Men, Chiefly at the Beginning of Islamism by Abu Zakariya Yabia el-Nawawi (Göttingen 1842) (Tahdhīb al-Asmā).

56 This collection only contains those parts of hadith which concern legal questions. The other collections overstep these boundaries and apart from legal and exegetical sentences of Tradition, mostly are devoted to moral and theological traditions. 
with other books in this field. It is clear that they neglected all of these books because of al-Bukhārī, but it is also clear that since the printing press made the others available, their study grows day by day. And we register this happy development because it not only widens the horizon of thinking, but slowly it creates a sense of historicity in the scholars of Islam when they discuss their scholarship.

Al-Ghazālì's (d. AH 505) The Revival of the Religious Sciences does not belong to this branch of scholarship, (Page 19) strictly speaking. I just list it here because perhaps the whole Muslim literature has never produced such a many sided application of traditions. We can fully study the Muslim morals and worldview according to the traditions in the I $b y \bar{a}$. As its title suggests, the author — who is one of the foremost scholars of Islam wanted to revive the increasingly neglected religious sciences. ${ }^{57}$ I do not want to judge here whether he fulfilled his goal, because I should talk more about the state of Muslim scholarship in the fifth century AH and its change after Ghazāli. It is enough to mention that posterity thought so, not only by naming him Mubyī al-Din 'the revivalist of religion' but also by granting him the title mujaddid as the greatest man in his century. Despite the great number of his enemies and jealousy, the common opinion among Arab scholars is that if it were possible to have another prophet after Muhammad, who is by the way the 'seal of prophets', al-Ghazāli would certainly be one. ${ }^{58}$

As I said, al-Ghazālī had many enemies, just as many as any reformer could have. Because al-Ghazāli was in the most noble sense of the word a 'reformer' and went against that direction of Muslim private and academic life which, as I experienced among Muslim scholars, is still in practice today. Then, just like now, the centre of gravity in all Muslim sciences was on the practical side of figh. To develop rules for the milliard problems of ritualistic life by a casuistry which attempts to take into consideration and to reflect on all possible cases - this is a dwarf problem of a giant science. Ablution, eating, praying, even possessing property, etc., these are all derived from Allah's will by speculation. Al-Ghazālī's great spirit and rich religiosity looked for ideas and a worldview, thus there is no wonder that he could not find it (Page 20) in the useless speculations of scholars. He wanted to create what was never there, believing that he was only reviving what had been there before, and this is why he named his project 'the revival of the religious sciences'. In the Foreword of his work he masterfully characterizes his age in a few words as an age which finds its scholars in qādīs and which admires the fatw $\bar{a}$ as the peak of scholarship, in a branch of science where the dreamlike abuses of formalism were cultivated. ${ }^{59}$

57 His biography was written by R. Gosche, 'Gazzālī's Leben und Werke', Abhandlungen der Königlichen Akademie der Wissenschaften zu Berlin aus dem Jahre 1858 (1859), 239-311.

58 Cf. Goldziher, 'Zur Charakteristik as-Sujūti's', 6.

59 Al-Suyūți wrote one work in which he dealt with the traditions used in the

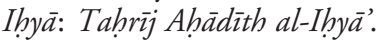


One cannot abolish fiqh, it can only be internalized. And one needs such a giant pioneering spirit to create a unified world view from a pile of external laws! But al-Ghazālī was aided by Tradition which was quite neglected in this field. He only had to peel off the husk of ritualism from the seed of internal spirit. Thus, of all scholars, al-Ghazālī became the most tireless cultivator of Tradition. ${ }^{60}$ We cannot but admire this huge intellectual work. In his project the author goes through each and every chapter of figh and we see this hard pile of petrified spirit leaving the refined mind and masterful pen of al-Ghazālī completely sublimated as a new substance. He pinned a chapter about scholarship to the beginning of the work, in which he explains his full project and everything that he thinks, feels and believes about this field, citing the most ancient scholars of Islam. Apart from this, the I hyc is useful also as a source for the cultural history of his age. The author as a pioneer cannot but look at his contemporaries, from time to time, and criticize their ossified view of life. It is done in four main parts; the first discusses 'ibādāt, i.e. the religious ministry to God, the second mu'amalāt (the practical circumstances of life), and the second part is divided into the discussions of munjiyyāt (morally advisable) and mublikāt (morally condemnable) things. ${ }^{61}$ (Page 21) There has yet not emerged a new al-Ghazālī in contemporary Islam. Islam has completely ceased to be productive. Its escape from the danger depends on which historically evolved school will decide its future. In my experience Islam finds its way now by opting for the dry system of figh. ${ }^{62}$

After Tradition the next is the so called $f i q b^{63}$ which is the canon law of Muslims since it is based on the Qur'ān and the Tradition. It is the most noble part of Muslim scholarship. It unites the religious, the civil and the penal codes and it regulates practically almost all Muslim issues.

${ }^{60}$ Ihy $\bar{a}, 1: 4$. [Goldziher possibly refers to the edition he brought to the Academy: Abū Hāmid Muhammad al-Ghazālī, Ihyyà 'Ulūm al-Dīn (4 parts in 2 vols, Cairo 1289/1872-3).]

${ }^{61}$ An overview of the whole work is in Flügel's Viennese catalogue, G.L. Flügel, Die arabischen, persischen und türkischen Handschriften der Kaiserl. Königl. Hofbibliothek zu Wien (3 vols, Vienna 1865-7), 2:91.

62 The aforementioned works of Tradition are respected only among Sunnis. The $S_{h i}^{i} a$ despise these because they demand that the isnād should go back to a member of Muhammad's family (abl al-bayt). The Sunni tradition does not have to conform to this condition because it is authentic enough if it [the isnād] goes back to one of the companions of the Prophet (al-ashāb). The $S h_{i}^{-} a$ have their own collections of Tradition which are not available in Sunni countries. It is certainly a mistaken idea that the $S h^{-} a$ would reject every authority except the Qur'ān, such as Tradition.

63 The word fiqh is a much wider concept as such; it acquired the meaning of 'canon law' when theology constructed artificial words for itself. Cf. Kasem Beg's studies about the word fiqh, M. Kasem Beg, 'Notice sur la marche et le progrès de la jurisprudence parmi les sects orthodoxes musulmanes', Journal Asiatique (Ser. 4) 15/1 (1850), 158-214, at 162. 
Although in theory and in practice figh has no other source than the kitāb (the Book) and hadith (Tradition), between the second and the third centuries [hijrī] we find many differences and opposing opinions about the right Muslim practice of religion; all of which founded their own schools and followers. Among these schools, or, better to say, rites, we find the following most famous and most enduring ones (though there are others as well): (1) which bears the name of Imam Abū Haniffa (d. AH 150) (2) the school of Imam al-Shāfíi (d. AH 204) (3) the school of Mālik b. Anas (d. AH 197) (4) and the school of Ahmad b. Hanbal (d. AH 241). ${ }^{64}$ They have their own geographical area. The hanafi school is found in European and Asian Turkey, the shäfi ${ }^{i} \bar{i}$ in Egypt (Page 22) and the mälikì in North Africa. Of these four legal schools the first is the most liberal and tolerant; and the Hanbalite is the most rigorous. According to Muslim statistics the most numerous is the hanafi community and proportionally the smallest is the hanbali one. It is evident from this fact that human kind, even Muslims, prefers comfort when given free choice. Man avoids anything that provides less freedom and independence for his will. Of the 10,216 students and 321 sheikhs at al-Azhar there are only thirty-four hanbali: four teachers and thirty students.

We should not suppose that these legal schools relate to each other the same way as Christian denominations. Despite the fact that, for example, the dogmatic difference between Hanbalites and the other schools concerning the idea of God is wider than between Sunnis and Shî îs in general, the followers of the four schools consider each other on equal footing. The teachers of the four schools give lectures every day in the same morning hour and in the same room in the centre of Muslim learning, in al-Azhar mosque in Cairo. We can find the imams and minbars (pulpits) of all four schools in all of the most noble mosques of Islam. It never occurred that one school excluded the others from the true faith, although the debate between them never ceased. The school of Abū Hanifa was especially attacked because they acknowledged analogy (qiy $\bar{a}$ ) as a source of law, in addition to the Book (kitāb) and the Tradition (hadìth). This analogical method produced many enemies among those who did not want to make any compromise with individual logic in questions of religious law.

But despite this important difference, no one ever denied salvation from the analogical school. I bring an example from the historical work of Maqqārī (vol. 1; page 814 in the Leiden edition) to illustrate that Muslim public sentiment always refuses intolerant phenomena. (Page 23) 'Abd al-Wahhāb b. Nașr al-Baghdādī, a māliki qua dì , wrote an apology of his own school against the others. When a shāfi $\bar{\imath} q \bar{a} d \bar{\imath}$ in Egypt received this work he threw it into the Nile. Our historian narrates that when Timur arrived

${ }^{64}$ Muslims usually include Sufyān al-Thawrī (d. AH 161) and Dāwūd al-Zāhirī (d. AH 270) among arkān al-sharī'a (the pillars of religious law). Cf. Journal Asiatique (Ser. 5) 15/1 (1860), 390. 
to Egypt, this qādì was punished by being captured and thrown into the Euphrates. The equality of legal schools was also represented [institutionally] in older times. For instance, there was a chief $q \bar{a} d \bar{\imath}$ of each four schools ( $q \bar{a} d \bar{\imath}$ al-qudēt) in Egypt. It is hence a huge mistake that the four schools are often called 'sects'. Muslims themselves call the schools madhhab, and they do not even make that distinction between Shīī and Sunnī which we attach to the meaning of sect.

Since the scholarly analysis and full understanding of Muslim life is impossible without knowing the laws and religious canons of Muslims, and since this knowledge can be only gained by the reasonable comparison and analysis of the four schools, I thought it proper to incorporate into our collection the basic books of the four schools and one commentary on each of them. I had considerable trouble in acquiring the hanbali book of law and I confess that I had many experiences suffering direct hanbali intolerance. - A work in three folios, which presents the casuistic application of legal theory, belongs to this same collection of canon law. It is a very popular book in the Muslim scholarly world and its author is Hasan al-Üzjandī al-Farghānī (d. AH 582) (Fatāwā Q Qàd̄ Khān). ${ }^{65}$ Since I especially focused on the comparative aspects of law when acquiring books, I could not miss a work which carries this out with much intelligence: al-Sha'rānīs The Scale of Truth. ${ }^{66}$ The author (Page 24) is a famous representative of Muslim mysticism (just like al-Ghazāli above). This direction of Muslim theology has been always in absolute opposition to the rigid representatives of fiqh, who spend their life in the billion branches of casuistry about the opus operatum and who reduce the spirit of Islam by a petrified formalism and an overemphasis on the ritual.

Al-Sha rānī wrote a work about the issues debated between the four schools, and, despite their difference, he was able to show where they agree. I have no doubt that the famous theosoph wanted to urge Islam to abandon the debates about rituals and casuistic reasoning. This goal is in harmony with Muslim, and in general, with all mysticism. I do not want to be lost in the whole Muslim literature, so I just cite one saying that I often heard

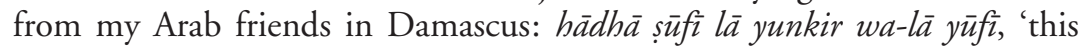
man is a Sufi, he does not deny and does not state anything' which means that 'he does not care about our religious and ritualistic distinctions'. By the way, I should add that the freethinker, who does not adhere closely to a religion, is usually called by two names: tabi $\bar{\imath}^{-} \bar{\imath}$ 'naturalist', and faylasüf 'thinker' ( dren, love to use the vowels in a word in the reverse order (for instance, góz instead of zóg [zawj] - husband; na'al instead of la'an-curse) and thus the

65 Hasan al-Ūzjandī al-Farghānī, Fatāwà Qàd̄̄ Khān (4 vols, Cairo 1865). There is a Calcutta edition as well: Fatawee Qazee Khan or the Institutes of Aboo Huneefa (4 vols, Calcutta 1835).

66 'Abd al-Wahhāb al-Sha' rānī, Mĩzān al-Haqq (2 vols, Būlāq 1279). 


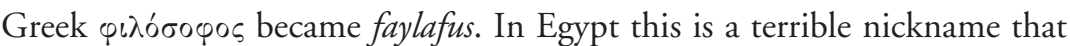
even the fellah uses in a very satirical sense. I find especially in the work of al-Shirbīni — which reflects the language use and customs of the peasant (ahl al-ary $\bar{a} f)$ - often the use of the word faylafus in this pejorative meaning: approximately meaning 'villain'. ${ }^{67}$ There is another name by which freethinkers are called, especially in Syria, after freemasonry (Page 25) found its home there: farmasün. But usually the name șüfi is the most fashionable and it matches here and there perfectly with the meaning of 'atheist'.

This is why the 'Sufi' al-Sha rānì's 'scale' is interesting from two points of view. First, it presents the debated points of ritual dogmas; second, because it makes visible the relation of moderate Sufism to the ritualists.

Let us switch now to philology, or better to say, to that part of Arab scholarship which is usually united under the title of adab. Adab means 'cultivation' and as the word already suggests it refers to that knowledge which, in truth, does not advocate the salvation of the soul but rather the social value [of its possessor]. The content of adab is not defined precisely; some define it wider, others narrower. It is understood usually that it includes the proper linguistics, the history of literature, especially its poetical part, historical and fictional tales, in short, everything which is not connected to religion but closely related to Arab life and language. The lexicographical literature of Arabs is so great that I don't dare to describe it in a few words. ${ }^{68}$ Al-Șăhib ibn 'Abbād (who lived in the fourth century after the hijra) said that his lexicographical books would only make the load of sixty camel-backs. ${ }^{69}$

And Arab scholars did not cease to produce new works after Ibn 'Abbād. Yet it is also true that what survived from these works and is still known among the Arabs is not the load of sixty camel-backs. In Cairo one 'donkey' [Goldziher uses this word in English] would comfortably run away with it. For, this scholarship was superseded by (Page 26) two works. These were written with the conscious aim of superseding their predecessors and making them superfluous. They indeed managed to supplant the previous lexicographical monographs and systematic dictionaries. The authors of these two works, the champions of Arabic lexicography, are far from being Arabs:

67 Yūsuf b. Muhammad al-Shirbīnī, Hazz al-Quhūffì Sharh Qașidat Abì Shādūf (Cairo 1274). Apart from this edition, which is completely sold out, there is another one, from Alexandria, a lithograph by Muḥammad Yahyāa al-Sa dì (1289/1872-3).

68 Its short but scant overview is given by E.W. Lane, 'Über die Lexicographie der Arabischen Sprache', Zeitschrift der Deutschen Morgenländischen Gesellschaft 2 (1849), 90-108. A nice overview but not all encompassing is given by Jalāl al-Dīn

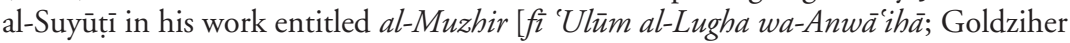
does not give the edition but likely it was 2 vols, Cairo 1282/1865-6], 1, 93.

69 I have discussed each group of the Arabic lexicographical literature in my studies which were published under the title 'Beiträge zur Geschichte der Sprachgelersamkeit bei den Arabern', Sitzungsberichte der phil. hist. Classe der kais. Akad. d. Wiss., Wien, LXVII; LXXII; LXXIII, 1870-3; in three parts. 
al-Jawharī is from Fārāb and he is the author of the work Täj al-Lugha wa'lȘihāḥ al-'Arabiyya; al-Fīrūzābādī, as his name shows, is from Fīrūzābād, and he is the author of the work known as $Q \bar{a} m \bar{u} s$ which means 'ocean' and which is translated also into Turkish. ${ }^{70}$ Arabs say about their language that it is a 'bottomless ocean' and this is why the dictionary writers name their works after the ocean. The previously mentioned Ibn 'Abbād calls his Arabic lexicon also an 'ocean' (al-mubit $t$ ); and the newest patriotic lexicographer of the Arab language, the Lebanese Christian al-Bustānī gave his two volume dictionary the title Mubìt al-mubìt ('the ocean of oceans') ${ }^{71}$ (which originally means 'the all-encompassing of the all-encompassing'; the Arabs call the ocean all-encompassing since it encircles the whole continent) and its extract was entitled The Drop of the Ocean. ${ }^{72}$ Furthermore, recently all dictionaries, even the non-Arabic ones, are called $Q \bar{a} m \bar{u} s$, for instance qūmūs inglìzin, faransāwi etc. (oceans of English, French, German, that is, dictionaries) just like they call every grammar Agrumyya (properly Ajurramiyya [Ajurrümiyya]) though originally this is the title of the basic work in Arabic grammar with which they usually start studying grammar. ${ }^{73}$

Since the vocabulary of Arabs is collected in Siḩa $\bar{a} h$ and $Q \bar{a} m \bar{u} s$, when the press started to pay attention to the Arabic texts, it focused on these two. The first (Page 27) started to be printed already in 1774 by Everhardus Scheidius ${ }^{74}$ but only the first instalment was published. Finally, nine years ago we got a full edition from Būlàq but unfortunately it is made without much skill. It is hard to imagine an Arabic philological work, especially a dictionary, without proper vocalization, because the meaning of words and grammatical forms depends on their vocalization. The Șiḩăh from Būlāq is completely devoid of such an accessory so in dictionary matters it can hardly be used as a reliable help. The $Q \bar{a} m \bar{u} s$ is much better published in India ${ }^{75}$ and in Turkey ${ }^{76}$ and even within Egypt its publication and analysis were taken great care of. The copy that I acquired for the Library of the Academy

${ }^{70}$ Our Arabic dictionaries are mostly the translations of these two basic works: Golius translated al-Jawharī; Freytag, without much refinement, published the summarized translation of the $Q \bar{a} m \bar{u} s$.

71 Buțrus al-Bustānī, Muhīt al-Muhìt (2 vols, Beirut 1867-9).

72 Buțrus al-Bustānī, Qațr al-Muhìt (2 vols, Beirut 1869).

${ }^{73}$ For the various editions of its author Muhammad al-Shanhāg î cf. J.T. Zenker, Bibliotheca orientalis (2 vols, Leipzig 1846-61), 1, 18 and 2, 11.

${ }^{74}$ E. Scheidius, Abu Nasri Ismaelis Ebn Hammad al-Gievharii Farabiensis purioris sermonis arabici Thesaurus vulgo dictus liber Sehah, s. a. 1. (4o, Herderovici Gelrorum 1774), particula I.

75 The Arabic text was published in Calcutta by El-Temini in 1817 (2 vols); its Persian translation in 1840. Next, in 1847 the full text again in 4 vols; not to mention its lithograph editions in Bombay and in Teheran.

${ }^{76}$ Its Turkish translation and commentary was printed in three folio volumes (Constantinople 1814-18); this was also published in a new edition in Būlāq in 1835 , again in three folio volumes. 
is printed by the Castelli press in Cairo (in four folio volumes), with full vocalization, whose quality is guaranteed by the name of the corrector, the already mentioned Nașr al-Hūrīnī. Apart from this there exists another edition, from the state press in Būlāq.

Fīrūzābādī's work superseded al-Jawharî̀s, and this is not a coincidence because the author consciously aimed at this. ${ }^{77}$ This is why the text of the Sih āh is neglected, which is exemplified by the Būlāq edition, while its rival, the Q $\bar{a} m \bar{u} s$, is diligently taken care of, and - as we have seen in many cases - it has been commented upon and translated. I want to mention only one commentary on the $Q \bar{a} m \bar{u} s$ that I have acquired for our collection of dictionaries: Sayyid Murtaḍā al-Zabīdī's Tāj al-'Arūs fì Sharh (Page 28)

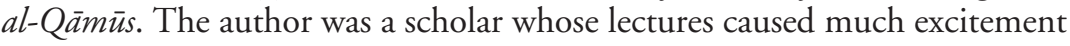
in Cairo in the middle of the last century. Had my report not exceeded already the space that is usually allocated for such things, I would mention the most valuable points of his interesting biography, relying on a famous contemporary historian whose work provides very valuable information about the Arabic scholarship of recent times in Egypt. ${ }^{78}$ It is enough to say that this commentary will make ten thick folios once its printing is finished. Only five volumes have been published so far; and I could only acquire three volumes. I could not buy the remaining two at any price although in the storehouse they still have around five hundred copies. And this has its own reason. A few years ago in Cairo a society was established for the spread of Arabic texts, called Khazinat al-Ma'ärif. The president was called 'Arifī Pasha and this Society started the publication of the ten volume Täj al-'Arūs. Exactly at the moment when the last two volumes were being published, the president of the Society had to flee to Constantinople from the legions of his debtors. All of his belongings were seized so the fourth and fifth volumes of the 'Crown of the Bride' were locked up and had to wait for the return of 'Arifi Pasha. The bulk of the commentary of the Q Q $\bar{m} \bar{u} s$ edited in Turkish and published in Constantinople is also a copy of the Täj al-'arüs. Lane also used this work when he compiled his great dictionary although at that time not even a letter of it existed in print. The diligent Lane had to use the manuscript of a mosque in Cairo. ${ }^{79}$

Between the lexicographical and belles lettres works a good transition might be Ahmad Efendi Fāris' Kitāb al-Sāq 'alā al-Sāq fì-mā huwa al-Fāryāq which was also published under the title La vie et les aventures de Fariac, relation de ses voyages avec ses observations critiques sur les Arabes et les autres peuples. ${ }^{80}$

77 Cf. Goldziher, Beiträge, II. Zur Gauhariliteratur (1872).

78 'Abd al-Rahmān al-Jabartī, Ajāìb al-Āthār fì 'l-Tarājìm wa'l-Akhbār. Now it is hard to find it in manuscript. Cf. A. von Kremer, Aegypten (2 vols, Leipzig 1863) 2, 325.

79 Cf. his introduction to the dictionary, page XVIII.

${ }^{80}$ Faris El-Chidiac, La vie et les aventures de Fariac, relation de ses voyages avec ses observations critiques sur les Arabes et les autres peuples (Paris 1855). 
This author is at the moment a Muslim and in Constantinople; (Page 29) he is the editor of the journal al-Jawä'ib; of all living Arabs he is the most skilful in his mother tongue and is the foremost scholar of language as well as a writer of belles lettres. He is the first of all Arabs who rose above sheer empirical data and ventured into the depth of etymological investigation. ${ }^{81}$ Of course, he had no schooling in this field and despite the fact that he could rely only on European investigations and acquire their methods, he belittles and shrugs his shoulders at European Orientalism and he childishly announces his opinion in several places in his works. Considering this bad habit, he is the complete opposite of his rival in Beirut, al-Bustānī, who is happy to use in his works the good results that he has acquired from European scholarship. In general Ahmad Fāris is able to express endless irony concerning Europe that he knows well; his work about Europe ${ }^{82}$ is really worth reading. His book, at the moment in front of us, is written in the form of a maqama and it is a fine example of the level at which the art of language stands today among Arab scholars. In addition, it is a valuable store of Arabic synonymy and lexicographical notes. It is worthy by all considerations to be included in your linguistic collection and to supplement the small collection of modern Arabic scholarship and poetry in the possession of the Library of the Academy, because one can extract many pearls of Arabic lexicography and antique words from the maqama of the author, though it is, from our point of view, very tasteless.

I have never seen a better compilation and commentary on those games, entertainments, food, etc. which are to be found among Arabs from the old times until today as in this work of Fāris. ${ }^{83}$

If I would want to talk in greater detail about The Book of Songs ${ }^{84}$ of Abū'l-Faraj al-Isfahānī (d. AH 316) which consists of twenty parts (Page 30) and which is now also in your collection and which is among the most important works that the state press in Būlāq brought to the world, I should write a separate essay. Kremer rightly calls this work an inexhaustible mine'. ${ }^{85}$ When the author presents all the Arab poets until the fourth century AH with their biographies and an abundant selection of their works, he not only opens up an important source for the history of Arabic lyrical literature, but also introduces his own contemporary culture and we cannot find a richer one in Arabic. However, Nöldeke says ${ }^{86}$ that the author is 'without any criticism, therefore he brings many tales and foolish things and does not respect the proper historical chronology. In addition, he favours

${ }^{81}$ In his work, Sirr al-Layālì fi'l-Qalb wa'l-Ibdāl (Istanbul 1284 [1868]).

${ }^{82}$ Kashf al-Mukhabbā à Funūn Urubā (Tunis [Goldziher does not give a year; this book had three editions in Tunis in 1864-66-67]).

83 El-Chidiac, La vie et les aventures, 263-73.

${ }^{84}$ Abū'l-Faraj al-Isfahānī, Kitāb al-Aghānī (20 vols, Būlāq 1856).

85 A. von Kremer, Kulturgeschichtliche Streifzüge auf dem Gebiete des Islams (Leipzig 1873), xiv.

86 Nöldeke, Geschichte des Qoran's, xviii. 
Shî'îs, thus his historical accuracy lacks'. But who can ask an author of the third century AH to discuss his material with Niebuhrian criticism? Wasn't it a useful thing to bequeath this material to us and to save it from oblivion? It would have been certainly a victim of oblivion in the following centuries when sheer speculation, the bliss of pragmatic wittiness, replaced poetical and literary taste. As to the shi ism of the author, in a forthcoming publication I will prove that the reverse judgement would be more justified in the case of the author of the Book of Songs. In one place ${ }^{87}$ he openly says that he does not want to reproduce a $\operatorname{sh}^{-\epsilon} \bar{i}$ poet's work because of his religious commitment. So it is really very hard to accuse him of favouritism for the $\operatorname{shi}^{-} a$ !

In this work we can also perceive how unfortunate it is that there has been no connection between European scholarship and typographical activity in the East and in Cairo in particular. Despite the fact that the Book of Songs was printed some years ago, it has no echo in European research, although already from manuscripts in Europe (Page 31) the importance of its treasures could be learned. ${ }^{88}$

I can be concise concerning the book of 'Antar, which was also included in thirty-two parts in this collection, ${ }^{89}$ because on another occasion I have been able to discuss it in this place [at the Academy] at more length. ${ }^{90}$ Now I say only that at this moment there are two competing editions in the Orient: the Cairo and the Beirut editions. I would like to point out their differences by citing a sentence from Habīb Gharzūzī, an Alexandrian literary scholar, who is dealing with the distribution of Beiruti books in Egypt. 'I wonder' - he said to me - 'how you can say that the Cairo edition of 'Antar is more useful than the Beirut one! The deceased Shaykh Nāsif, who was in charge of the Beirut edition, carefully left out everything that was said by Muslims disrespectfully about Christians. So Europeans can enjoy the superb novel of 'Antar much better than the Cairo edition where everything is included what the cursing Muslims wrote'. I naturally could not make myself understood by Gharzūzī that we look at 'Antar with other glasses than the Lebanese Maronites and that in our eyes exactly the untouched editions mirror the real spirit of those circles that we wish to study precisely from such products!

Under this heading I have to discuss another very famous work that is in the philological part of the collection. It is a quarto volume in two volumes under the title The Book of Proverbs by al-Maydānī. ${ }^{91}$ First I have to warn you that what is called in Arabic mathal, and in Hebrew mashal, is rather a parable than a proverb. The characteristic feature of the mathal - without

87 Al-Isfahānī, Kitāb al-Aghānī, vol. 7.

${ }^{88}$ J.L. Kosegarten initiated its publication, but only one volume was printed. Alii Ispahanenis liber cantilenarum magnus (Grippelswaldiae 1840.)

89 Qișat 'Antar (32 vols, Cairo 1286/1869-70).

90 Goldziher, A nemzetiségi kérdés az araboknál, 38.

91 al-Maydānī, Amthāl al-'Arab (2 vols, Būlāq 1284/1867-8). 
which it is not a mathal - is that it does not use the same method as the proverb, that is, it does not say a general truth, deducted from experience, (Page 32) which then can be applied to each case. Such a saying is not a real Semitic mathal, regardless that it is represented in such a form in one book of the Old Testament which was called mistakenly 'the mashal of Salamon'. The real mathal starts as a concrete case which has a certain lesson or which was the occasion for a certain saying and that lesson or saying later was applied to similar cases. ${ }^{92}$ It is in this meaning that the writer of the Bible often says 'you shall become mashal, that is, your case will be used in later times as a mashal; and this is the meaning the Qur'ān employs when it says: 'a mathal will be applied on you', that is, as the coin is minted following a model ${ }^{93}$ (ضرب) [al-Baqara, 2:27], the mathal forms such a model for the coming ages. Let us deal now only with the Arab mathal. Most of these are deducted from the famous stories of pre-Islamic periods and usually mean those, so we often find such expressions: 'the parables and stories of Arabs and their days of battle'. ${ }^{94}$ A mathal can originate in historical events or in personal stories. It is clear that it is not without importance for the researchers of a mathal, now current among the ordinary people, to know its original context, without which the parable loses its significance and wit. To cite an example, there is an Arab saying: 'your people can be angry with you but the moon can't'. This mathal would be very obscure had we not known its original context. The men of the Tha laba tribe once, before Islam, debated among each other whether on the fourteenth of each month the moon disappears before sunrise or (Page 33) only when the sun becomes visible on the horizon. They went to a man whom they chose together to become their judge. When they arrived, the speaker of one party said to the judge: 'Sir, the opponents from my people are angry with me and they contradict what I state about the moon'. And the judge said: 'Well, your people can be angry with you but the moon can't'. This is the basis of the parable and it is always applied when someone wants to deny obvious things. But one who does not know this little story cannot understand the parable. Thus al-Maydānī did a huge service to the Arabs and to us who deal with their writings and antiquities when in his above-described book he collected all their parables and explained their context and origins. He was not the sole parable collector and parable scholar yet his book became the most famous and most widely used. The reason for this is that the alphabetical arrangement eases its use, apart from the fact that his collection is very rich - it contains more than 6,000 parables and his explanations are mostly pertinent and authentic. It superseded even the similar work of

92 The essence of the mathal is discussed in a very detailed way in Ibn al-Athīr al-Ghazarī's book about writing style: al-Mathal al-Sä ir fì-Adab al-Kätib wa'l-Shā'ir (Būlāk 1282/1865-6), 13-14.

${ }_{93}$ Petrarch says exactly in this sense: Ma ben veggi'hor si come al popol tutto Favola fui gran tempo...

94 Amthäl al-'arab wa-Ayyāmuhum. 
his famous contemporary, al-Zamakhsharī (d. AH 538), which is not that rich but arranged also alphabetically. ${ }^{95}$ No wonder that smaller and nonalphabetically but thematically arranged collections could not gain popularity in competition with al-Maydānīs nice work. ${ }^{96}$ This is why the attention of Orientalists in Europe also focused on al-Maydānī’s work. ${ }^{97}$ Especially Schultens, the immortal Dutch scholar, who edited significant portions of texts from al-Zamakhsharī (Anthologia sententiarum Arabicarum cum scholiis Zamachsjarii Lugd. Batav. 1773), prepared two specimens from the book of al-Maydānī whose second volume was printed only after the great scholar's death. ${ }^{98}$ Rosenmüller in Leipzig in 1796, Habicht in Breslau in 1826, (Page 34) and our compatriot Ferenc Dombay in 1805 also studied al-Maydānī. Only Freytag published the full work: Arabum proverbia, vocalibus instruxit latine vertit, commentario illustravit et sumtibus suis edidit (Bonnae 1838) in 3 vols. This work provides al-Maydānī's [original] text [of the parables] and its translation but instead of the clever Arabic explanations of al-Maydānī we have to be satisfied with the well-known dog Latin of the professor in Bonn, which does not give precisely and properly the meaning of al-Maydānī's very clear explanations. The Būlāq edition is of more use than the Bonn edition in all respects, which is anyway scarcely available. Let me note that al-Maydānī ['s book] is among those few good products which the state printing house produced in its first period.

I do not have to discuss the current state and development of historical literature in Arabic scholarship, because I would only repeat what I have already said in my mother tongue at another place. ${ }^{99}$ I would like to highlight here only that history writing Arabic started, just like in the case of any other peoples, with chronological narration but later it developed through its own critical and analytical phases. The critical study of history started by someone called Ibn al-Tiqțiqa [al-Ṭiqtaqà̄] in his work al-Fakhri It was so unpopular among the Arabs that it was suppressed, literally speaking, and it had to be discovered in the only manuscript in Paris in which this clever historical work survived and on the basis of which Ahlwardt published it. ${ }^{100}$ To some extent al-Makkarī also belongs to this critical scholarship. He wrote about the history of Andalusia, that is, the Moorish period of Spain in a long historical work. In fact, his excessively poetic and

95 Zenker, Bibliotheca orientalis, nr. 412-13.

96 Flügel, Die arabischen, persischen und türkischen Handschriften, 1:300, nr 383.

97 This is also the order of parables in the collection of al-Khuzzāmī, edited by Bertheau (Göttingen 1836).

98 Cf. bibliography in Zenker, Bibliotheca orientalis, 1, 50-3.

99 I. Goldziher, 'A történettudomány állása az arab irodalomban' in 2 parts, Protestáns Tudományos Szemle, 1872. [Goldziher gives 'Ballagi Tudományos Szemléje’ but there was no such periodical. The Protestáns Tudományos Szemle was a supplement to the Protestáns Egyházi és Iskolai Lap between 1869-72, both edited by M. Ballagi].

100 W. Ahlwardt (ed.), Elfachri: Geschichte der islamischen Reiche vom Anfang bis zum Ende des Chalifates von Ibn Etthiqthaqa (Gotha 1890). 
musical but empty style damages the critical attitude. ${ }^{101}$ Both of these works (Page 35) are in your library. A very adequate addition to this small Arabic history collection is therefore the great eight-volume work of someone who is rightly called 'the Arab Montesquieu'. And this is not an exaggeration. Anyone who reads the Prolegomena historica of Ibn Khaldūn (since this is the name of our writer), which is now available in a French translation, ${ }^{102}$ will doubtless finish this book with the impression that its author rose above the matter of history in an astonishing intellectual flight. He transcended the thought and system of all ages, including his own fourteenth century, by constructing the history of cultural ideas of the whole human race. $\mathrm{He}$ was the first and last great Muslim authority — let's not forget that he was a chief $q \bar{a} d \bar{\imath}$ - who took such a step which here in Europe the then contemporary history writing could not dream of. He declared that miracles such as traditions and news about unnatural things do not belong to history. Of course, our author understands differently from us what is natural and unnatural. For instance, he believes that witchcraft has some essence, etc. But wasn't it a giant step for a chief $q \bar{a} d \bar{\imath}$ in the fourteenth century, when talking about the critique of Tradition, to declare internal logic as its first criteria? He is not satisfied with how his predecessors had been regarding Tradition, i.e., that the chain of Tradition should be traced back unbroken to the Prophet and that the individuals in the chain should be good believers and authentic. But on the other hand, he is a good enough Muslim not to question the dogmatic understanding of Prophethood and to declare the then fashionable Greek philosophy harmful because it was the opposite of the religious dogmas. ${ }^{103}$

It would be very useful to analyse thoroughly the literary and scholarly personality and style of such an author as Ibn Khaldūn. That this branch of literature has been so far neglected is testified to by the fact that hardly anyone has ventured into such work, (Page 36) except the weak experiment of a Swedish author writing in Italian. ${ }^{104}$ There are especially two issues, less connected to his style, but rather to the scope of his work, in which Ibn Khaldūn also superseded the traditional boundaries of Arab history writing. First, Ibn Khaldūn wanted to write a world history, as much as he could, and though it was unsuccessful because of the quality of his sources, or rather due to his ignorance of languages, we can still say that no other Arab history writer could have ever embraced such a wide spectrum of topics. Second, he wanted to render a service to Africa, his homeland in the widest sense, by pioneering the ethnography of its inhabitants. Although Ibn Khaldūn was proud of his Arab descent and nationality with full

101 It was printed two times: Būlāq 1279/1862-3 (4 vols) and Leiden 1855-60 (5 vols).

102 Prolegomènes d'Ibn Khaldoun, trad. par M. de Slane (Paris 1863).

103 E. Quatremère (ed.), Muqadimmat Ibn Khaldūn (Paris 1858), 210 and 220.

104 Gräberg di Hemsö, Notizia intorno alla famosa opera istorici d'Ibnu Kaldun (Firenze 1834). 
consciousness (he proves proudly his origins from South Arabia), ${ }^{105}$ still he had enough historical attention to appreciate the history of the Berber tribes which at that time still lived in large numbers around his native city and to the south in Africa. And in fact, we find an amazingly prudent ethnographic and political history of the Berbers by our author, whose [book] is almost the only surviving source in this field of African history. ${ }^{106}$

It is characteristic of our author that he includes in history the discussion of the history of fine arts, belles lettres and the art of war. Coquebert de Montbret first analysed the section on architecture in 1827, and an anonymous Italian discussed first the section on the development of writing (Rome 1820; Articolo di Eben Caliduno sull'antica e varia arte di scrivere appresso gli Arabi). His history of Arab belles lettres and science is not yet presented to the public; it is a shame that Slane did not translate these parts of the Prolegomènes. (Page 37) As to the Būlāq edition of this precious historical work, ${ }^{107}$ on this example we can especially register a very inconvenient and, for the reader, a very disturbing mistake in these [Būlāq]-products. Oriental printed texts are usually at best good copies of a random manuscript which, if the corrector is careful, are improved with remarks in the margins. They are not produced in the same way as those in Europe which are compiled with a critical comparison of several codex-versions of the same text. And lacuna is very frequent in manuscripts, especially in those from later ages, which are far from the autograph. In the case of a lacuna, the products of Būlāq show an empty space. This is the most common in the case of proper nouns when a writer [copyist] could not find out the right reading of the strange-sounding proper noun in front of him. It is frequently the case especially with the Berber and other, non-Arabic, proper nouns. In our book it occurs even more often because, since he was an African, the best basic codices of Ibn Khaldūn are written in the so-called maghribī script which some mashriqi authors cannot read. ${ }^{108}$ The Ibn Khaldūn print of Būlāq might have been copied after exactly such a codex which may be the second copy with mashriqi script. Therefore we frequently meet lacuna with a remark on the margin bayäd fi'l-asl which means it is white in the original'. The lacuna's empty space is white therefore the Arabs call it 'whiteness'. It is such a pity that, among all Būlāq products, the total absence of horror vacui troubles this famous work the most.

105 He sketches a very precise genealogy in his autobiography which is at the end of the eighth volume of his full historical work and which is in the beginning of Slane's translation.

106 This part is translated into French by Slane, Histoire des Berbèrs et des dynasties musulmanes de l'Afrique septentrionale (3 vols, Algiers 1851-2). The text of this section is also published by Slane (Algiers 1847-51).

107 'Abd al-Rahmān b. Muhammad Ibn Khaldūn, Kitāb al-'Tbar (7 vols, Būlāq $1284 / 1867-8)$.

108 The beautiful codex in Leiden is similarly in maghribī script. cf. Goldziher, A nemzetiségi kérdés, 45. 
This work of Ibn Khaldūn in translation is also part of Turkish scholarship; the full work was translated (by Gevdet [Cevdet] efendi) and published in Constantinople. Apart from this, there is a separate translation of the Prolegomena in one folio volume which was published in Cairo by Castelli. I emphasize this particular detail because this book is advertised as if it were printed in Constantinople. As I heard from the publisher himself, he did this because books in Turkish printed in Constantinople (Page 38) sell better than those [Turkish books] printed in Egypt. At the same time I was informed that most of the books printed in the Orient have the same doubtful indication of the date of publication. In such cases, only those who know the fonts recognize the false printing dates.

Arab writers usually have one colossal weakness. This is that they usually promise in the Preface or in the Introduction much more than what they give in the work. Thus one meets disappointments all too often. How many times this happened to me in that period of my youth when I devoted almost all my time to Arabic manuscripts. A boasting Introduction, like a jack-o'-lantern, enticed me and I eagerly set myself to the actual content of the promising work, only to finish the search of the moth-eaten codex with disappointment. Ibn Khaldūn himself in the actual historical part of his work falls much more behind what was promised in the introductory volume. But even with this drawback Ibn Khaldūn surpassed the whole of Arab historical scholarship. In his case a thick volume, which drifts the reader into a whole current of beautiful ideas, precedes the bitter moments of disappointment.

It is different in the case of another historical work which is also included in your collection, and entitled The Perfect. ${ }^{109} \mathrm{It}$ is among the newest products of the Būlāq printing press: it was printed when I stayed in Cairo in February this year. This is the work which I have mentioned above whose margins contain three smaller other works: the books of al-Qaramānī, Ibn Sihnā, and al-'Utbī. Here I only mention the main work. It was published in Leiden by Tornberg with the title Chronicon Ibn al-Athīrī. Dr Socin says in a letter, published in Zeitschrift der Deutschen Morgenländ. Gesellschaft, vol. XXVII (1873), p. 154: 'Hiebei sei bemarkt, dass gegenwärtig Ibn al-Athīr in Bulak nachgedruckt wird und zwar (Page 39) vollständing von Anfang an'. This suspicion about a Nachdruck is not really grounded. Reprints, to be sure, are not forbidden by Oriental laws, and profiteering printers do exploit this legal gap. I have seen with my own eyes in Matba'at al-Ma'ärif ('the press of sciences') printing house in Beirut how they set the commented edition of Harīrī according to the Būlāq edition, sans gêne; though the scholar-owner of the press (al-Bustānī) could add certainly ex suis. But in the case of Ibn al-Athïr I did not find Mr. Socin's hasty judgement valid. How could one possibly reprint such a long work which is printed in its entirety for the first time in this presumed Nachdruck? It is a

109 'Izz al-Dīn ibn al-Athīr, Tārīkh al-Kāmil (12 parts, Būlāq 1290/1873-4). 
pity that some suppose that Arabs in general are villains. The Arab nation, on the contrary, is very earnest!

Tornberg rightly calls the work in question Chronicon; but when we start to describe this work we have to note that the author, writing in the seventh century AH, rises above the normal method of a chronicon. Unlike the chronicles, he does not split a historical event, which occurs through a number of years, into parts, but describes it as one harmonious segment. It is clear that his unit of analysis is not the order of successive years, but the historical material, the event itself. He writes his history until the year AH 629, and he would have continued had he not died. The bulk of Arab historians have no prescribed framework - at least those who did not attain the high quality of al-Maqqarī or Ibn Khaldūn - and they do not write the history of an age, a nation, or a movement but they follow the thread of the fate of the world until a year they could reach. In this regard our book contains an interesting Preface from one of the authors in the margins in which he says: 'The second part starts at the birth of Muhammad and lasts until the Almighty Allah wants'. The history writer thus has no precise, finalized plan, when he starts to work, so he writes as long as his ink, his pen, or his life last and the earlier or later ending does not affect the excellence of the work. (Page 40) The small step, taken by Ibn al-Athīr, was fully conscious. As he indicates in his Preface he wanted to present history progressively. But there are some other, related points in which his work represents a novel phase. He was the first to embrace the whole history of Islam evenly as one material of history. He says this quite openly: 'His predecessors discussed their material very one sidedly. The historian living in the Eastern side of Islam neglected the Maghrib and vice versa'. ${ }^{110}$ Ibn al-Athīr embraces the entire history of Islam equally; thus in this regard we can admit that he named his book rightly al-Kämil, 'The Perfect'. He pays attention to the Central Asian territories too, which most other sources neglect, since they focus on Syria and Egypt. He is also notable in another respect, namely, that he covers the Biblical story for the first time faithfully, keeping even the original proper names, ${ }^{111}$ and he is free of those ridiculous misunderstandings that we find so often in Mas ùdī and the like.

But we do not find any trace of that higher understanding of history that the author so emphasized in the Introduction. He debates there with those who underestimate the importance of history and he enumerates the importance and value of this branch of scholarship. His words very much resemble those of the above-mentioned Ibn Țiqțiqa [Ṭiqțaqā'] and I have reason to suppose that our author knew him, although he does not mention this. Yet, one piece of advice from this historian was neglected by the Muslim world,

110 Wa'l-sharqī min-hum qad akhalla bi-dhikr akhbār al-gharb wa'l-gharbī qad ahmal ahwāl al-sharq.

111 Only Ibn Qutayba is an exception; he clearly indicates his knowledge of the Old Testament in his Kitāb al-Ma'ärif (published by Wüstenfeld). 
and even Ibn al-Athīr does not mention it: to introduce history into school education. We find this idea in Arabic for the first and last time in al-Fakhri ; only he [Ibn Tiqutaqầ] had the courage to (Page 41) state that historical education is more useful for the infant intellect than Harīin's art of empty words and clanging phrases. ${ }^{112}$

While one of the above two authors wrote a history of Islam, and the other a history of the world, the excellent al-Maqrīiè represents a monographer with his book about Egypt which is also a part of your collection. ${ }^{113}$ Everything that has been written about Egypt can be traced back to al-Maqrīzi as the primary source, with the exception of 'Abd al-Lațif. It is hard to find in world literature a more extensive and detailed treasury of sources than this one. I say 'treasury of sources' because the two folios of al-Maqrīzī make a little library in itself. He not only provides history, but also ethnography, topography, historical geography, cultural studies, everything which is important for a historian of Muslim Egypt. There is no mosque, church, or synagogue since the establishment of Cairo which he has not accounted for; there is not a single library, school, hospital, bath, or entertainment institution of which he has not told a story; streets, markets, squares, hills are described with such a faithful attention to detail and painstaking elaboration that we can only view with amazement the fruits of the tireless diligence invested into this work. A recent Arab critic said correctly that Maqrīiñ, in fact, provides an inventory of Egypt. We happily forgive the chronological dryness of the historical part in exchange for the giant ethnographic and cultural-historical material which he presents to us with such taste. Of all works we can study the manners and history of the Copts in particular in this one. We can judge its value for the history of the Mamluks from the fact that Quatremére, Histoire des Sultans Mameluks is nothing but Maqrīzī's translation with notes. This author focused on certain points of history that no Arab historian paid attention to, for instance, the structure of administration, (Page 42) the development of offices, education, health care, etc.; therefore no wonder that this work is already out of stock in Egypt where it bears a double importance.

On the other hand, the Arabs think about history (al-tārikh) in a much wider sense than we usually do. Hence you should be not surprised that I close the description of historical works and in general this report with a zoological dictionary which, according to the Arab hierarchy of sciences, belongs to the category of 'history'. Al-Damīin wrote such a dictionary for Arabs about all animals which figure in the old poetry, the Tradition, etc. However, this work, entitled The Life of Animals, apart from the structure of a dictionary, contains so abundant information about historical details that it is rightly regarded as a proper source of history. It contains many

112 Ahlwardt (ed.), El-Fachri, 4.

113 Taqī al-Dīn al-Maqrīzī, Kitāb al-Mawā'iz wa'l-I'itibār bi'l-Dhikr al-Khitat wa'l-Äthār (2 vols, Būlāq 1270). 


\section{IGNÁC GOLDZIHER'S REPORT ON THE BOOKS FROM THE ORIENT}

quotations from lost works in particular, and for this reason Muslim authors love to borrow facts directly from al-Damīin. To give an idea to the reader about the quality of the wide excursions of this author, it is enough to mention that in this zoological dictionary we find the history of the caliphate as well as the intermezzo of the article insān, the human being. However, al-Damīin's work is important and useful because he relates in every article what information can be found about the animal in question in the Tradition, poetry and literary criticism. It is especially important for cultural history because we can find a complete series of popular superstitions with enlightening examples about animals in each article. And this is a very useful method in a corpus which is so poor in secondary encyclopedias as in Arabic.

I would like to finish my report with a last remark and a wish. The remark is that this report does not include the smaller books in each category; and my wish is that this collection may be enriched as much as possible so that in the homeland it may serve the scholarship to which it belongs in the most productive way.

Address for correspondence: mestyan@fas.harvard.edu 